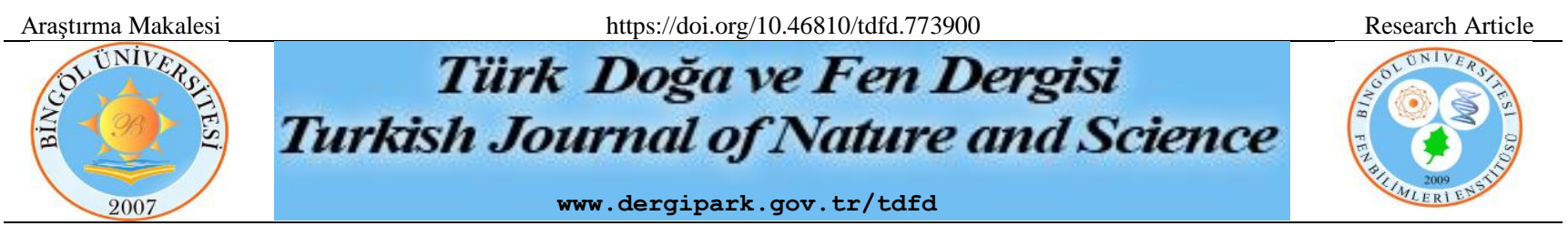

\title{
Vinç Kancalarının Farklı Malzeme Özellikleri ve Yükleme Kapasitelerine Göre Yorulma Dayanımlarının İncelenmesi
}

\author{
Ali SARI ${ }^{1}$, Ömer Faruk NEMUTLU ${ }^{2 *}$ \\ ${ }^{1}$ İstanbul Teknik Üniversitesi, İnşaat Fakültesi, İnşaat Mühendisliği Bölümü, İstanbul, Türkiye \\ ${ }^{2}$ Bingöl Üniversitesi, Enerji, Çevre ve Doğal Afet Çalışmaları Uygulama ve Araştırma Merkezi, İnşaat Mühendisliği \\ Bölümü, Bingöl, Türkiye \\ Ali SARI ORCID No: 0000-0002-6888-1276 \\ Ömer Faruk NEMUTLU ORCID No: 0000-0001-7841-3911 \\ *Sorumlu yazar: ofnemutlu@bingol.edu.tr
}

(Alınış: 25.07.2020, Kabul: 15.12.2020, Online Yayınlanma: 30.12.2020)

\begin{abstract}
Anahtar
Kelimeler

Vinç

Kancas1,

Kirılma

Mekaniği,

Yorulma

Dayanımı,

Statik Yük

Testi

Öz: Genel olarak endüstride kullanılan vinç kancalarının nakliye, inşaat ve imalat gibi çeşitli sektörlerde önemli bir görevinin olması araştırmacıların bu alanda çalışmalar yapmasını gerektirmiştir. En genel anlamda şekillerine göre isimlendirilen kancalar basit kancalar, çift ağılı kancalar ve lamelli kancalar olarak sınıflandırılırlar. Kancalar, işlev olarak yer yer değişim gösterebilmesinin yanında genel olarak bir malzemeyi kaldırmak, bir yerden başka bir yere taşımak ve ağır yükleri yükseltmek amacıyla kullanılırlar. Emniyetli bir şekilde kaldırma, taşıma ve yükseltme işlerini yapabilmesi ve çok büyük ve tekrarlı yüklere maruz kalmasından dolayı en büyük çekme yükleri yani yük kapasiteleri, yorulma testleri ve analizleri yapılarak yorulma ömürlerinin belirlenmesi büyük önem taşımaktadır. Bu çalışmada kapsamında 2 ton karbon ve alaşım, 3 ton karbon ve alaşım, 15 ton alaşım ve 25 ton karbon kancalar çeşitli statik ve yorulma testlerine tabii tutulmuştur. Yorulma testlerinden elde edilen veriler yardımıyla kanca tiplerine ait Gerilme-Döngü Sayısı (S-N) eğrileri oluşturulmuştur. Çalışma kapsamında yorulma analizlerinde kullanılacak S-N eğrileri bir başka deyişle Wöhler eğrileri bir malzemenin hasar meydana getiren çevrim sayısına karşı gelen gerilme genliğinin büyüklüğünü ifade eden eğrilerdir. Bu çalışmada farklı malzemelerden yapılmış ve farklı statik yük kapasitesindeki kancaların yorulma dayanımları, elde edilen S-N eğrileri kullanılarak karşılaştırılmıştır. Çalışma sonucunda, karbon kancaların alaşım kancalara göre daha yüksek çekme yük kapasitesine sahip olduğu, yorulma ömrüne kancaların büyüklüğünün etki etmediği, karbon kancaların alaşım kancalara göre daha uzun yorulma ömrüne sahip olduğu gözlemlenmiştir.
\end{abstract}

\section{Evaluation of Fatigue Strength of Crane Hooks Considering Material Properties and Load Capacities}

\section{Keywords Crane Hook, Fracture Mechanics, Fatigue Strength, Static Load Test}

\begin{abstract}
The fact that crane hooks used in the industrial industry have an essential role in various sectors such as transportation, construction, and manufacturing required the researchers to work in this field. Hooks, which are named according to their shapes in the most general sense, are classified as simple hooks, double rim hooks, and lamellar hooks. Hooks are generally used to lift objects, to move them from one place to another, and to lift up heavy loads. Since they are exposed to large and repetitive loads due to their ability to safely lift, transport heavy loads, it is of great importance to determine the strength and the fatigue life of the hooks by analysis or testing. In this study, fatigue and static tests are performed for 2-ton carbon, 2-ton alloy, 3-ton carbon, 3-ton alloy, 15-ton alloy, and 25-ton carbon hooks. Stress-Number of Cycles (S-N) curves, in other words Wohler curves, are developed utilizing data obtained from the fatigue tests. S-N curves illustrates the stress level on a material for a given number of cycles that cause damages. It is possible to identify a mechanical part, for example, the cumulative damage of a hook, and the loading history of that part by the S-N curve. In this study, the fatigue lives of hooks with different material properties and sizes are compared. As a result of the study, it has been observed that carbon hooks have higher tensile load capacity than alloy hooks, hook size does not have any significant effect on the fatigue life of the hooks, and the carbon hooks have a longer fatigue life than the alloy hooks.
\end{abstract}




\section{GİRiş}

Vinç kancaları nakliye, inşaat ve imalat gibi çeşitli endüstrilerde genellikle malzemeleri bir yerden başka bir yere taşımak, bir malzemeyi kaldırmak veya ağır yükleri yükseltmek için kullanılan oldukça önemli bir bileşendir. Vinç kancaları gezer vinç, portatif vinçler, kule vinç, yükleyici vinç gibi yükleri tutmak ve kaldırmak için kullanılan makinelerin önemli bir elemanıdır. Büyük yükler altında önemli gerilmelere maruz kalan kancalar, belirli bir süre sonunda gerilme birikmesi sonunda göçme durumuna ulaşırlar. Vinç kancasının genel şeması Şekil 1'de gösterilmiştir.

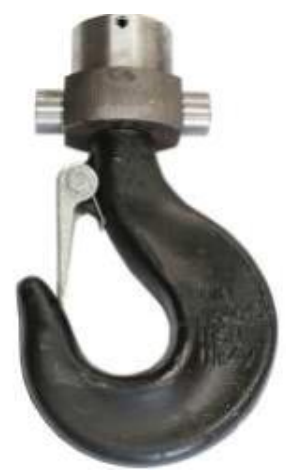

Şekil 1. Vinç Kancası[1]

Temel olarak bir kaldırma zincirinin bir halkasına veya bağlantısına veya bir zincir veya kablo soketinin pimine geçmek için tasarlanmış bir kaldırma tertibatıdır. Yamuk, dairesel, Kare, I kesit, T kesit ve üçgen kesitli vinç kancaları yaygın olarak kullanılmaktadır. Vinç kancaları hayati bileşenlerdir ve çoğu zaman nihayetinde arızaya yol açan büyük miktarda gerilim birikimi nedeniyle göçmeye maruz kalırlar. Vinçler sürekli yükleme ve boşaltma işlemine tabi tutulur. $\mathrm{Bu}$, vinç kancasının yorulmasına neden olur. Vinç kancasında çatlak gelişirse, kancanın kırılmasına ve ciddi kazalara neden olabilir. Eğilme gerilmesi, çekme gerilmesi, aşınmaya bağlı olarak kanca kesitinin zayıflaması, aşırı yüklemeye bağlı olarak plastik şekil değişimlerinin meydana gelmesi, termal yüklemelere maruz kalmak kancaların hasar uğramasında rol oynayan etmenlerdir. $\mathrm{Bu}$ nedenle en büyük performansın hatasız olarak sunulması için tasarlanmalı ve üretilmelidir. Vinç kancasının yanlış tasarımı önemli kazalara neden olur [1]. Her yıl yanlış kaldırma prosedürleri yaralanmalara, çalışmaların durmasına ve mal kaybına neden olur. İnsanların, makinelerin, yüklerin, yöntemlerin ve çalışma ortamının yeterli güvenlik önlemlerinin tam olarak alındığı zamanlarda, kaldırma kazalarının azaltılabileceği görülmektedir. Genellikle kanca üzerinde kancaya takılan yüklerin sıyrılıp düşmemesi için kanca üzerine güvenlik mandalı eklenir. Ayrıca kancaların tasarımı sırasında güvenlik katsayılarının yüksek olması gerekir. Kökçü'nün çalışmasında belirttiği gibi en ağır yük taşıyan kancalarda güvenlik katsayısı en küçük 5 olmalıdır [2, 3]. Ayrıca kanca üzerinde belirli bölgelerin güvenlik açısından dikkatli şekilde kontrol edilmesi gerekmektedir. Şekil 2'de belirtilen bölgelerde; 1. Bölgede ve 3. Bölgede aşınma ve yıpranma olup olmadığı, 2. Bölgede ise bükülme ve çatlak olup olmadığı düzenli olarak kontrol edilmelidir [4-6].

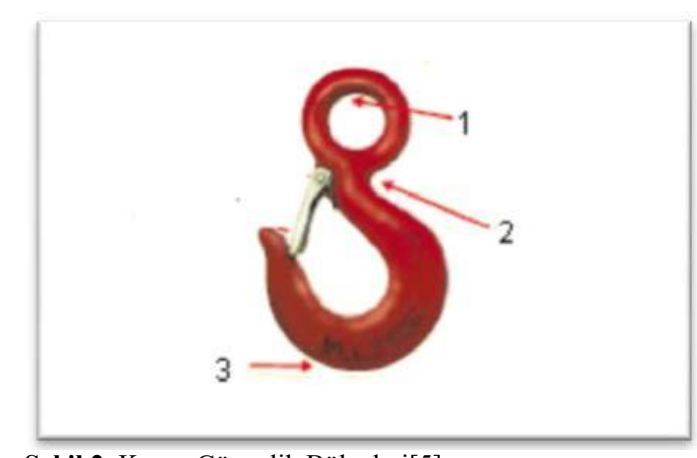

Şekil 2. Kanca Güvenlik Bölgeleri[5]

Kancalar genellikle şekillerine göre isimlendirilirler. Kaldırma makinelerinde kullanılan kancalar genellikle 3 sınıfa ayrılmaktadır. Bunlar sırasıyla basit kancalar, çift ağızlı kancalar ve lamelli kancalardır [2, 4, 7]. Şekil 3'te çeşitli kanca tiplerine ait örnekler verilmiştir. Kancalar üretimi sırasında serbest ya da kalıpta dövülerek, DIN 15400 standartlarına uyumlu malzemelerden üretilmektedir. $\mathrm{Bu}$ malzemelerden üretilen kancalarda kullanılan çelikler ise DIN 17102 ve DIN17103 standartlarına uymalıdır $[8,10]$.

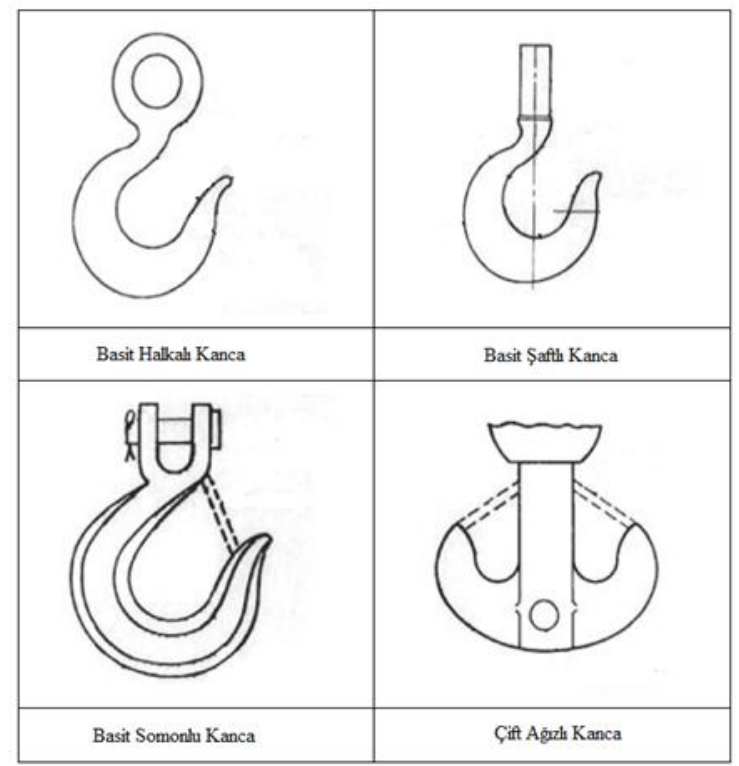

Literatürde vinç kancalarının statik ve yorulma analizleriyle ilgi bir çok çalışma mevcuttur. Yapılan çalışmalarda genellikle kancaların yükleme altındaki davranışı, çatlak ilerlemesi, S-N eğrileriyle yorulma analizleri ve farklı kesitlerdeki kanca tiplerinin davranışlarının karşılaştırılması üzerinedir. Sonsino, yaptığı çalışmada yüksek döngüde yorulma rejimine sahip elemanların yorulma mukavemetinde S-N eğrilerine bağlı olarak azalma olduğu sonucuna değinmiştir [11]. Qin vd., yapmış oldukları çalışmada nümerik bir BIRKPM metodu oluşturarak gerilme analizi yapmışlar ve bu alanda kullanılan sonlu elemanlar yöntemine ek bir çözüm önermişlerdir [12]. Torres vd., kancalarda göçmenin mevcut olan kontrolsüz bir kaynağın ısıdan etkilenen bölgesindeki çatlaklardan başladığını gösteren bir çalışma yapmışlardır ve bu çalışmanın sonuçları kancalardaki gevrek davranış ile 
ilgili önemli bilgiler vermektedir [13]. Vinodh ve Ravikumar yaptıkları çalışmada sonlu elemanlar yönteminde kullanılan malzeme ve yük girdileri ile en büyük stres ve en büyük sapmaların olasılıksal bir değerlendirmesini yaparak vinç kancalarının tasarımında güvenlik faktörünün rastgele seçilmesinin önlenebileceği üzerine araştırmalar yapmışlardır [14]. Sundriyal ise kancadaki göçmelerin kancanın geometrisine ve malzeme çeşidine bağlı olduğunu incelemek üzere 3 farklı kesite sahip kancalar üzerinde analizler yapmış ve çalışmanın sonucunda $\mathrm{T}$ kesite sahip kancaların en küçük gerilme değeri üzerlerine aldığını göstermiştir [1]. Bergaley ve Purohit ise yaptıkları çalışmada kancaları sonlu elemanlar yöntemine bağlı kalarak modelleyip bu modelden elde ettikleri sonuçları deney ortamında elde ettikleri sonuçlar ile karşılaştırmışlardır. Geometrik özelliklerin ve kesit tiplerinin değiştirilmesinin gerilmeyi etkilediğini göstermişlerdir [15]. Desai ve Zeytinoğlu, vinç kancalarının geometrik özellikleri üzerine çalışmışlardır. Tasarım ve optimizasyon üzerine yaptıkları çalışmada farklı kesitler üzerinde yaptıkları analizlerde trapez kesitin gerilme konsantrasyonu göz önüne alındığında en verimli seçenek olduğu sonucuna varmışlardır[16]. Sahu vd., kanca tiplerinden trapez kesite sahip bir kanca üzerinde kancanın geometrik boyutları üzerinde değişiklikler yapıp gerilme ve şekil değiştirmeleri incelemişlerdir. Kancanın boyun bölgesindeki boyutun değiştirilmesinin gerilmeyi etkilediği görülmüştür [17].

Çalışma kapsamında yorulma analizlerinde kullanılacak S-N eğrileri bir başka deyişle Wöhler eğrileri bir malzemenin hasar meydana getiren çevrim sayısına karşı gelen gerilme genliğinin büyüklüguünü ifade eden eğrilerdir(Şekil 4). Mekanik bir parça örneğin bir kancanın birikimli hasarını ve bu parçanın yükleme geçmişini S-N eğrisi ile belirlemek mümkündür.[18, 20]. $\mathrm{S}-\mathrm{N}$ eğrilerini elde edebilmek için metal eleman deney makinesine yerleştirilir. Hasar veya çatlak meydana gelene kadar eleman yüklenir. Ama bu işlemi farklı gerilme seviyelerinde ve farklı metal eleman üzerinden tekrarlanması gerekmektedir. Yüklemeler eleman üzerine yapılıp sonuçlar alındıktan gerilme ve her bir gerilmeye karşı gelen çevrim sayısı eksenlerine göre S-N eğrisi oluşturulur. $\mathrm{Bu} \mathrm{S-N}$ eğrilerinin plastik bölge, elastik bölge ve sonsuz ömür gibi çeşitli bölgeleri vardır ve bu bölgeleri ayıran çekme gerilmesi, akma gerilmesi ve yorulma sınırları vardır. Çekme gerilmesi çevrim sırasında hasar oluşması için gereken gerilme seviyesini ifade eder. Akma gerilmesi sınırı elastik ve plastik bölgeyi ayıran nokta olarak tanımlanır ve Yorulma sınırı, bu bölgenin üstündeki çevrimlerde hasar meydana geleceği anlamını taşır(Şekil 5) [21].

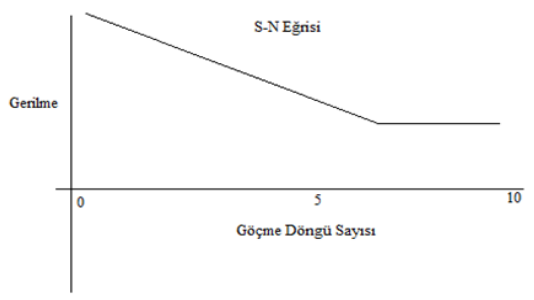

Şekil 4. Tipik bir S-N eğrisi

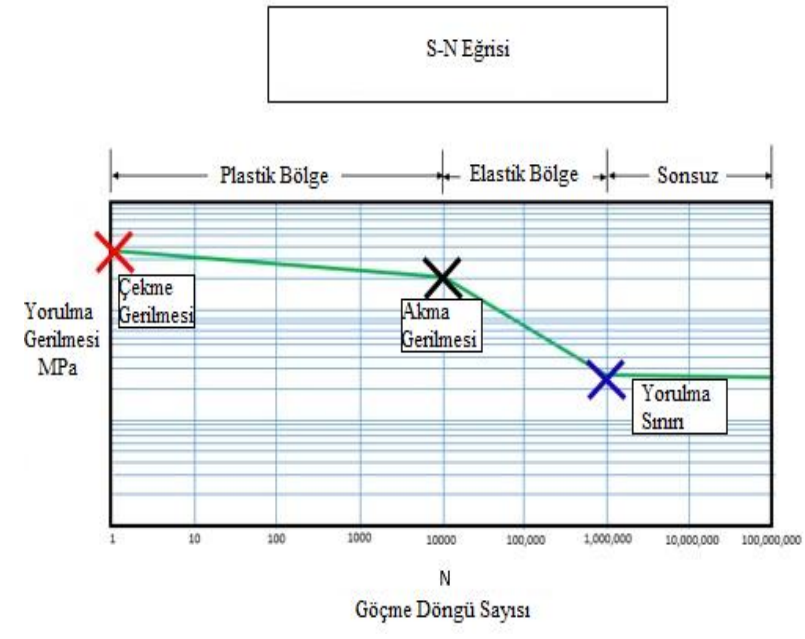

Şekil 5. S-N Eğrisinin Sınırları

$\mathrm{Bu}$ çalışmada da S-N eğrileri çeşitli kanca tiplerinin yorulma analizlerinde kullanılacaktır. Çalışmanın amacı alaşım ve karbon malzemelerden imal edilmiş, 2 ton, 3 ton, 15 ton ve 25 ton yükleme kapasitesine sahip kanca tiplerindeki kancaların yükleme testi ve çevrimli yükler altında yorulma testleri yapılarak çeşitli kancaların yükleme kapasitesi ve malzeme özelliğine göre yorulma ömürlerini belirlemektir. $\mathrm{Bu}$ amaçla çeşitli analizler farklı kanca tipleri üzerinde yapılmış ve ilerleyen bölümlerde detaylı olarak verilecektir. Elde edilen sonuçlar detaylı olarak gerekçeleri ile irdelenmiştir.

\section{MATERYAL VE METOT}

$\mathrm{Bu}$ bölümde çalışmada kullanılan malzemeler, bu malzemelere ait özellikler, test setupları hakkında bilgiler, kancaların geometrik özellikleri, kullanılan deney ekipmanları hakkında bilgiler verilecek ve uygulanan deneylerin nasıl gerçekleştiğinden bahsedilecektir. Statik test kurulumu $800000 \mathrm{Ib}$ ile $5000000 \mathrm{Ib}$ yük kapasitesi aralığına sahip universal bir test cihazıdır. Yorulma testi cihazı ise farklı yük kapasitesindeki kancalara ve çalışma yüklerine göre değişiklik gösterecek şeklinde hazırlanmıştır. Çalışma kapsamında yapılacak olan yorulma testleri için 6 farklı kanca tipi seçilmiştir. Bunlar, 2 tonluk karbon, 2 tonluk alaşım, 3 tonluk karbon, 3 tonluk alaşım, 15 tonluk alaşım ve 25 tonluk karbon şaft kancalarıdır. Çalışma içerisinde yapılan değerlendirmelerde farklı tipteki kancalara isimlendirmeler verilmiştir. Çalışmanın bu bölümden sonraki kısımlarında bu kısaltmalar kullanılacaktır. İsimlendirme kapasitesi ve üretildiği malzemenin baş harfleri şeklinde olacaktır. Örn: 2 Tonluk Karbon Kanca: 2TKK. Bu isimlendirme düzenine göre 6 farklı kanca tipinin sırasıyla kısaltmaları şu şekilde olacaktır: 2TKK, 2TAK, 3TKK, 3TAK, 15TAK, 25TKK. Analiz testleri, seçilen örneklerin hem nihai yük testini hem de yorulma testini içerir.6 nihai yük testi ve 47 yorulma testi yapılmıştır. Universal test makinelerinde (kapasiteleri 360 ton ile 2300 ton arasinda değişen) 6 adet statik nihai yük testleri yapıldı. Statik testlerde, yorulma testlerine tabi tutulmamış vinç kancası örnekleri (yani, yeni örnekler) göçme testine tabi tutulmuştur. Test makineleri çiktı birimi olarak pound(Ib) kullandığ 1 için sonuçlar bu birim cinsinden 
dikkate alınmıştır. Yorulma testlerinde, çeşitli tip ve ebatlardaki kancalar hızlı bir şekilde yüklendi ve belirtilen yük ile boşaltıldı. $\mathrm{Bu}$ yükleme döngüsü göçmeye kadar sürdürüldü. Toplam 47 test yapıldı. Kancaların çalışma yükleri 2 ton, 3 ton, 15 ton ve 25 ton idi. Yorulma testleri sırasında kancalara farklı miktarda yük uygulanmıştır. Uygulanan bu farklı miktardaki yükler, çalışma yükünün yüzdesi ile tanımlanır. Yüzde çalışma yükü(\%ÇY) aşağıdaki denklem 1 ile hesaplanır:

\%ÇY= (Maks. Uygulanan Yük - Min. Uygulanan Yük) x 100

/ Kanca Kapasitesi

(1)
Tablo 1, çalışma ve test yükleri ile farklı tipteki kancaları göstermektedir. Ayrıca beklenmedik sap arızaları nedeniyle 2 ton alaşım ve 3 ton alaşım kancalar için ek yorulma testleri yapıldı.

Deneyler sırasında uygulanan farklı yüklerde $2 \mathrm{TKK}$ için 9, 2TAK için 10, 3TKK için 6, 3TAK için 10, 15TAK için 9, 25TKK için 3 adet yorulma testi uygulanmıştır. Testler için kancalar, yükü en küçük ve en büyük değer arasında değiştirebilen bir test aparatına monte edildi. Kancalar tipik olarak göçmeye ulaşana kadar çevrim uygulanmıştır.

Tablo 1. Yorulma Test Numuneleri ve Yükleri

\begin{tabular}{|c|c|c|c|c|c|c|}
\hline \multirow{2}{*}{$\begin{array}{l}\text { Çalışma } \\
\text { Yükü } \\
\text { ton }\end{array}$} & \multirow[b]{2}{*}{$\begin{array}{l}\text { Güvenlik } \\
\text { Katsayısı }\end{array}$} & \multirow[b]{2}{*}{$1 *$ ÇY(Ibs) } & \multicolumn{2}{|c|}{ Test Yüklemeleri } & \multirow[b]{2}{*}{$3.0 *$ ÇY(Ibs) } & \multirow[b]{2}{*}{$\begin{array}{c}\text { Ultimate Tasarım Yükü } \\
\text { Ibs }\end{array}$} \\
\hline & & & $1.5^{*}$ ÇY(Ibs) & $2.0 *$ ÇY(Ibs) & & \\
\hline $2 \mathrm{TKK}$ & 5 & 4409 & 6614 & 8818 & 13228 & 22046 \\
\hline $3 \mathrm{TKK}$ & 5 & 6614 & 9921 & 13228 & 19481 & 33069 \\
\hline $25 \mathrm{TKK}$ & 5 & 55115 & 82672 & 110230 & 165345 & 275575 \\
\hline 2TAK & 4.5 & 4409 & 6614 & 8818 & 13228 & 19481 \\
\hline 3ТАK & 4.5 & 6614 & 9921 & 13228 & 19481 & 29762 \\
\hline 15TAK & 4.5 & 33069 & 49603 & 66138 & 99207 & 148810 \\
\hline
\end{tabular}

\section{BULGULAR}

\subsection{Statik Test Sonuçları}

Toplam yedi adet statik test yapılmıştır. Test örnekleri şu numuneler seçilmiştir: 2TKK, 2TAK, 3TKK, 15TAK ve 25TKK. Ek yorulma testi için 3 ton alaşımlı kanca numuneleri kullanıldığından, 3 ton alaşımlı kancalar üzerinde statik bir test yapılmamıştır. Her test örneği, şekil değiştirmeleri ölçmek için çeşitli konumlarda strain gageler ile donatılmıştır. Toplamda, kancalarda dokuz adet strain gage bulunmaktadır: ikisi şaftta, dördü yanlarda, ikisi arkada ve biri önde olmak üzere. 25 tonluk kancada sadece yedi adet strain gage yerleştirilmiştir, çünkü gövdede strain gage bulunmamaktadır. Yapılan yükleme testleri sonucunda elde edilen en büyük çekme yüklerinin testlerde kullanılan kanca tiplerine göre değişimi Tablo 2'de verilmiştir. Tablo 2'deki verilen en büyük çekme yükleri incelendiğinde 2 tonluk kancalardan alaşım kancanın en büyük çekme yükünün karbon kancaya göre daha düşük değerler aldığı görülmektedir. Ayrıca yorulma testlerine tabi tutulduktan sonra alınan numunelerin benzer nihai yük kapasitelerine sahip olduğu gözlenmiştir. 2 ton kapasiteye sahip karbon kanca incelendiğinde yorulma testlerinden sonra elde edilen çekme yükleri sırasıyla 14.33 ve 13.65 ton elde edilmiştir. Sadece statik teste tabi tutulan 2 tonluk karbon kancanın en büyük çekme yükü 13.95 ton olarak elde edilmiştir. Bu nedenle, bir kanca yük kapasitesinin düşük çalışma yükü koşullarında yorulma testine tabi tutulduktan sonra önemli ölçüde değişmediği sonucuna varılabilir.

\subsection{Yorulma Testi Sonuçları}

$\mathrm{Bu}$ bölüm içerisinde bulunan aşağıdaki alt bölümlerde, yorulma testinin sonuçları özetlenmektedir. Sonuçlar çelik türüne ve çalışma yüküne göre altı gruba ayrılmıştır. Tablo 3 ila Tablo 8 arasındaki tablolar, göçme yükünü, göçme döngü sayısını ve göçme modunu gösterir. Her tablonun ardından, tipik göçme modlarının, çalışma yüküne karşı döngü sayısının bir grafiği Şekil 6'dan Şekil 11'e kadar verilmiştir. Tablo 3, 2 tonluk karbon kancaya ait yorulma test sonuçlarını Şekil 6 ise 2 tonluk karbon kancaya ait yorulma test verilerini vermektedir. Tablo 3'te verilen değerlere bakıldığında 4 ve 8 numaraları testlerin yanında işaretlemeler vardır. $\mathrm{Bu}$ testlerde görüldüğü üzere döngü 2 ve 6 milyonlara kadar devam etmesine rağmen kancalarda göçme meydana gelmemiştir. $\mathrm{Bu}$ nedenle bu test setleri $\mathrm{S}-\mathrm{N}$ eğrilerinin belirlerken uygun bir seçim yapabilmek için hesaplamalardan hariç tutulmuştur.

Tablo 2. Statik Test Sonuçları

\begin{tabular}{cc}
\hline Kanca Tipleri & Çekme Yükleri \\
\hline 2 TKK & $13.95 \mathrm{t}$ \\
2TKK (Testten Sonra \#4) & $14.33 \mathrm{t}$ \\
2TKK (Testten Sonra \#8) & $13.65 \mathrm{t}$ \\
2 TAK & $10.41 \mathrm{t}$ \\
3 TKK & $19.5 \mathrm{t}$ \\
3 TAK & $* * * * *$ \\
15 TAK & $62.14 \mathrm{t}$ \\
25 TKK & $127 \mathrm{t}$ \\
\hline
\end{tabular}




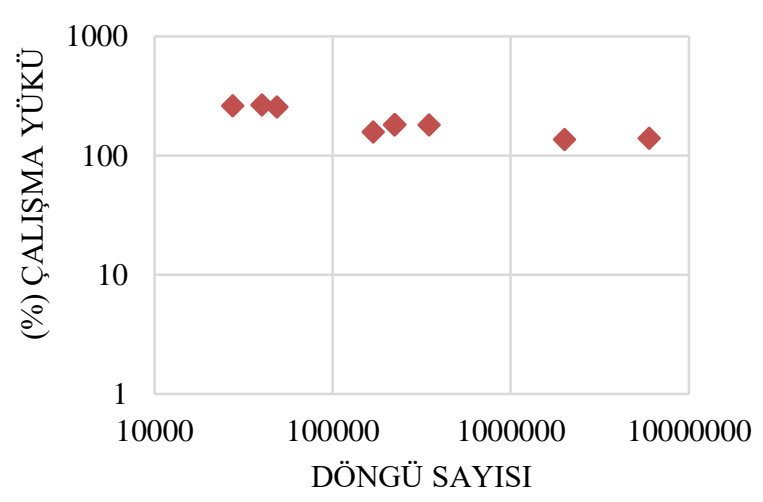

Sekil 6. 2 ton karbon kanca test verileri

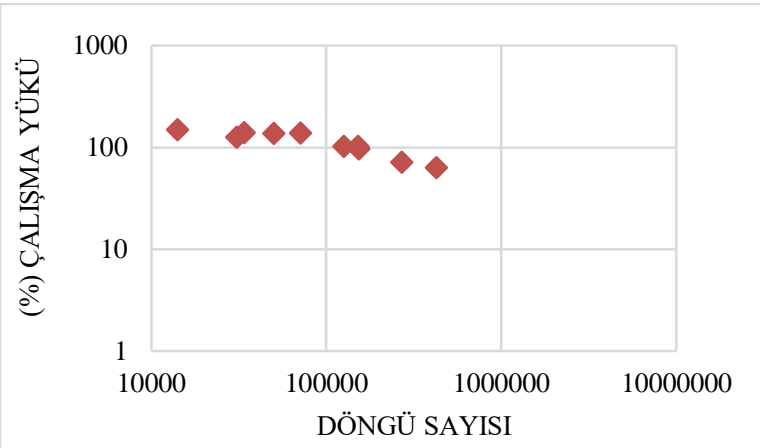

Şekil 7. 2 ton alaşım kanca test verileri

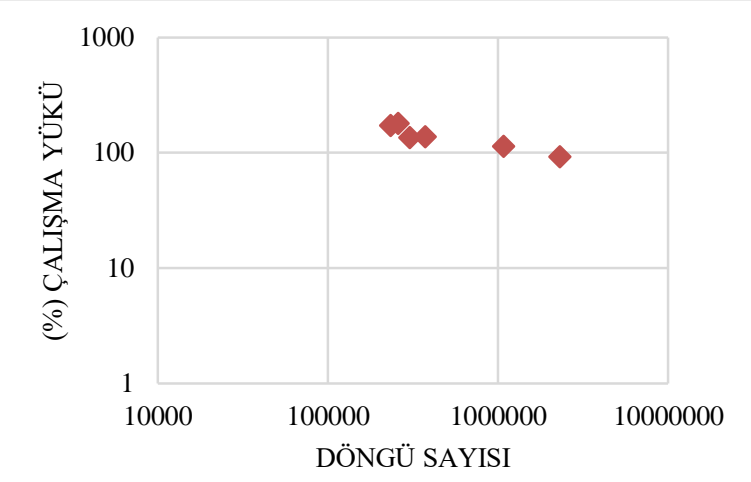

Sekil 8. 3 ton karbon kanca test verileri

Tablo 3. 2 tonluk karbon kancaya ait yorulma test sonuçları

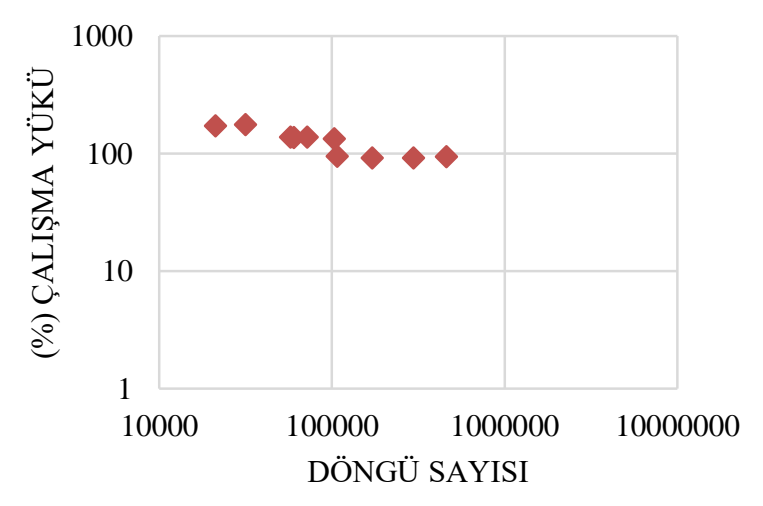

Şekil 9. 3 ton alaşım kanca test verileri

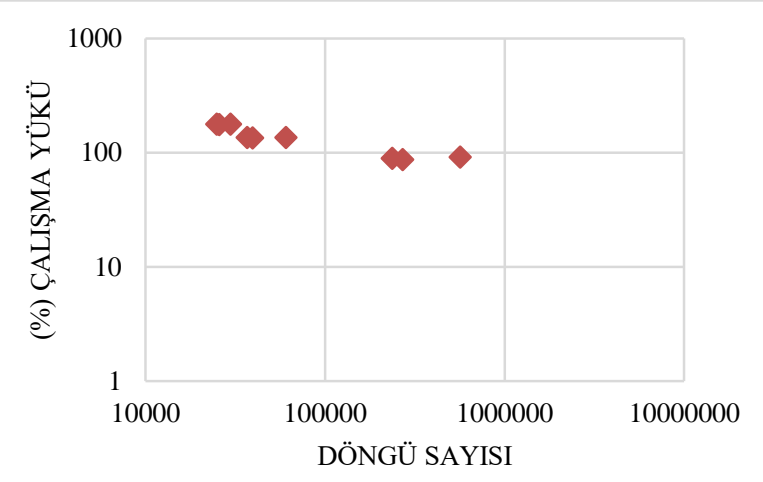

Şekil 10. 15 ton alaşım kanca test verileri

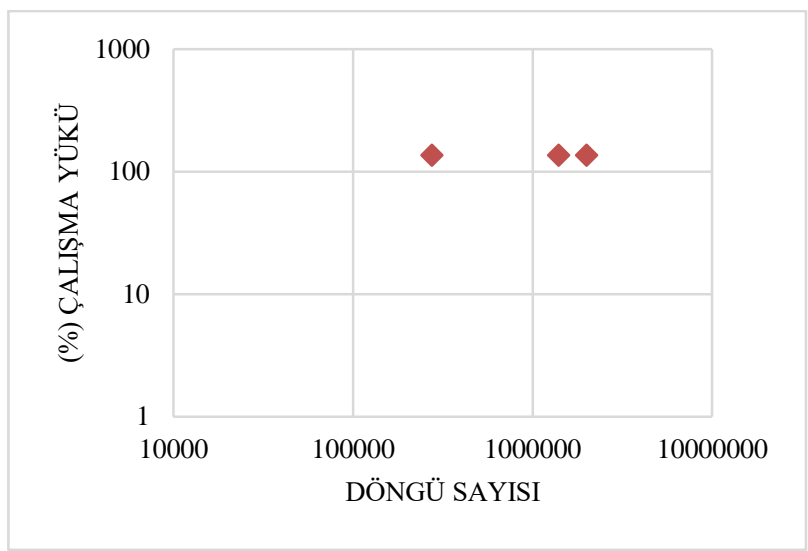

Şekil 11. 25 ton karbon kanca test verileri

\begin{tabular}{llllll}
\hline Test Numarası & Çalışma Yükü(\%) & Döngü Sayısı & \multicolumn{2}{c}{ Yorulma Test Yükleri (lbs) } & Göçme Modları \\
& & & min & max & Kancada göçme \\
\hline 1 & 181 & 347800 & 280 & 8,260 & Kancada göçme \\
2 & 182 & 223800 & 240 & 8,250 & Kancada göçme \\
3 & 181 & 222100 & 240 & 8,230 & Göçme Yok-Test Durduruldu \\
$4 *$ & 136 & 2000000 & 300 & 6,300 & Kancada göçme \\
5 & 266 & 40200 & 260 & 12,000 & Kancada göçme \\
6 & 261 & 27500 & 280 & 11,780 & Kancada göçme \\
$7 *$ & 48600 & 322 & 11,617 & Göçme Yok-Test Durduruldu \\
9 & 140 & 6000000 & 392 & 6,564 & Kancada göçme \\
\hline
\end{tabular}


Tablo 4. 2 tonluk alaşım kancaya ait yorulma test sonuçları

\begin{tabular}{|c|c|c|c|c|c|}
\hline \multirow[t]{2}{*}{ Test Numarası } & \multirow{2}{*}{ Çalışma Yükü(\%) } & \multirow{2}{*}{ Döngü Sayısı } & \multicolumn{2}{|c|}{ Yorulma Test Yükleri (lbs) } & \multirow{2}{*}{ Göçme Modları } \\
\hline & & & $\min$ & $\max$ & \\
\hline 1 & 138 & 71400 & 362 & 6466 & Şaftta göçme \\
\hline 2 & 136 & 50200 & 305 & 6298 & Şaftta göçme \\
\hline 3 & 139 & 34000 & 290 & 6425 & Şaftta göçme \\
\hline 4 & 125 & 30700 & 449 & 5964 & Kanca Gövdesinde Göçme \\
\hline 5 & 148 & 14100 & 432 & 6976 & Kanca Gövdesinde Göçme \\
\hline 6 & 102 & 126200 & 393 & 4890 & Kanca Gövdesinde Göçme \\
\hline 7 & 102 & 151800 & 401 & 4906 & Kanca Gövdesinde Göçme \\
\hline 8 & 96 & 153400 & 205 & 4427 & Kanca Gövdesinde Göçme \\
\hline 9 & 63 & 426300 & 372 & 3154 & Kanca Gövdesinde Göçme \\
\hline 10 & 71 & 269600 & 318 & 3440 & Kanca Gövdesinde Göçme \\
\hline
\end{tabular}

Tablo 5. 3 tonluk karbon kancaya ait yorulma test sonuçları

\begin{tabular}{|c|c|c|c|c|c|}
\hline \multirow{2}{*}{ Test Numarası } & \multirow{2}{*}{ Çalışma Yükü(\%) } & \multirow{2}{*}{ Döngü Sayısı } & \multicolumn{2}{|c|}{ Yorulma Test Yükleri (lbs) } & \multirow{2}{*}{ Göçme Modları } \\
\hline & & & $\min$ & $\max$ & \\
\hline 1 & 92 & 2308700 & 559 & 6617 & Kanca Gövdesinde Göçme \\
\hline 2 & 135 & 303400 & 659 & 9558 & Kanca Gövdesinde Göçme \\
\hline 3 & 137 & 374100 & 584 & 9628 & Kanca Gövdesinde Göçme \\
\hline 4 & 113 & 1078100 & 607 & 8060 & Kanca Gövdesinde Göçme \\
\hline 5 & 172 & 233700 & 527 & 11917 & Kanca Gövdesinde Göçme \\
\hline 6 & 179 & 259200 & 367 & 12174 & Kanca Gövdesinde Göçme \\
\hline
\end{tabular}

Tablo 6. 3 tonluk alaşım kancaya ait yorulma test sonuçları

\begin{tabular}{|c|c|c|c|c|c|}
\hline \multirow{2}{*}{ Test Numarası } & \multirow{2}{*}{ Çalışma Yükü(\%) } & \multirow{2}{*}{ Döngü Sayısı } & \multicolumn{2}{|c|}{ Yorulma Test Yükleri (lbs) } & \multirow{2}{*}{ Göçme Modları } \\
\hline & & & $\min$ & $\max$ & \\
\hline 1 & 172 & 21200 & 428 & 11778 & Şaftta göçme \\
\hline 2 & 92 & 298400 & 599 & 6671 & Şaftta göçme \\
\hline 3 & 137 & 60400 & 563 & 9611 & Şaftta göçme \\
\hline 4 & 138 & 57800 & 358 & 9507 & Kanca Gövdesinde Göçme \\
\hline 5 & 138 & 72200 & 234 & 9332 & Kanca Gövdesinde Göçme \\
\hline 6 & 92 & 171800 & 556 & 6641 & Şaftta göçme \\
\hline 7 & 94 & 461200 & 501 & 6696 & Kanca Gövdesinde Göçme \\
\hline 8 & 95 & 107600 & 264 & 6562 & Şaftta göçme \\
\hline 9 & 134 & 103450 & 634 & 9467 & Kanca Gövdesinde Göçme \\
\hline 10 & 176 & 31700 & 526 & 12156 & Kanca Gövdesinde Göçme \\
\hline
\end{tabular}


Tablo 7.15 tonluk alaşım kancaya ait yorulma test sonuçları

\begin{tabular}{llllll}
$\begin{array}{l}\text { Test } \\
\text { Numarası }\end{array}$ & $\begin{array}{l}\text { Calışma } \\
\text { Yükü(\%) }\end{array}$ & $\begin{array}{l}\text { Döngü } \\
\text { Sayısı }\end{array}$ & $\begin{array}{l}\text { Yorulma } \\
(\mathbf{l b s}) \\
\mathbf{m i n}\end{array}$ & $\begin{array}{l}\text { max } \\
\text { mäkleri }\end{array}$ & Göçme Modları \\
\hline 1 & 136 & 37000 & 561 & 45555 & Kancada göçme \\
2 & 135 & 60900 & 837 & 45421 & Kancada göçme \\
3 & 91 & 566900 & 813 & 30855 & Kancada göçme \\
4 & 89 & 237600 & 672 & 29998 & Kancada göçme \\
5 & 178 & 29900 & 895 & 59683 & Kancada göçme \\
6 & 176 & 25900 & 910 & 58947 & Kancada göçme \\
7 & 177 & 25000 & 869 & 59544 & Kancada göçme \\
8 & 87 & 271600 & 809 & 29703 & Kancada göçme \\
9 & 134 & 39600 & 844 & 45239 & Kancada göçme \\
\hline
\end{tabular}

Tablo 8. 25 tonluk karbon kancaya ait yorulma test sonuçları

\begin{tabular}{|c|c|c|c|c|c|}
\hline Test Numarası & Çalışma Yükü(\%) & Döngü Sayısı & $\begin{array}{l}\text { Yorulma } \\
\text { (lbs) } \\
\text { min } \\
\end{array}$ & $\begin{array}{ll}\text { Test Yükleri } \\
\text { max }\end{array}$ & Göçme Modları \\
\hline 1 & 136 & 1398000 & 705 & 75644 & Kancada göçme \\
\hline 2 & 136 & 276400 & 676 & 75712 & Kancada göçme \\
\hline 3 & 136 & 2000000 & 751 & 75682 & GöçmeYok-Test Durduruldu \\
\hline
\end{tabular}

\subsection{Yorulma Amalizi}

Yorulma ömrü, yorulma testlerinden elde edilen S-N eğrilerinin kullanımına dayanmaktadır. Kullanılan S-N eğrileri malzemelerin kullanıma devam edebilme olasılıklarıyla ilişkilidir. Temel olarak tasarım S-N eğrileri şu şekilde verilebilir(Denklem 2,3):

$\log _{10} N=\log _{10} \bar{K}-m x \log _{N} \Delta L$

$\log _{10} N=\log _{10} K-z x$ StndrtSap

Burada; $\Delta \mathrm{L}$, çalışma yükünün yüzdesi olarak yorulma yük oranını, $\log \mathrm{K}^{-}, \log \mathrm{N}$ ekseni ile tasarım $\mathrm{S}-\mathrm{N}$ eğrisinin kesişimini, $\mathrm{m}, \mathrm{S}-\mathrm{N}$ eğrisinin ters eğimini, $\mathrm{N}$, öngörülen döngü sayısını, K, S-N eğrisinin ortalaması ile ilişkili sabit, $\mathrm{z}$ ise ortalama dağılımından elde edilen standart sapma sayısını ifade etmektedir.

Aşağıdaki tablolarda Tablo 9'dan Tablo 13'e kadar 2T Karbon, 2T Alaşım, 3T Karbon, 3T Alaşım ve 15T Alaşım kancaları için S-N Eğrisi parametreleri verilmiştir. Yetersiz veri nedeniyle, 25 Tonluk karbon kanca için S-N eğrileri oluşturulmamıştır. Parametreler, Şekil 12 ila 18 'de gösterilen S-N eğrilerini oluşturmak için kullanılmıştır. S-N eğrilerini tanımlamak için iki eğim kullanılmıştır. Bahsi geçen şekiller ve tablolar aşağıda sırasıyla verilmiştir.

Aşağıda karbon ve alaşım kancalar için verilen S-N eğrileri karşılaştırıldığı zaman karbon kancalar için S-N eğrilerinin, alaşım kancalar için S-N eğrilerinden daha yüksek bir grafik çizdiği görülebilir. $\mathrm{Bu}$, karbon kancaların alaşım kancalardan daha yorulmaya dayanıklı olduğunu göstermektedir.
Tablo 9. 2TKK S-N eğrisi parametreleri

\begin{tabular}{lllll}
\hline \multirow{2}{*}{ S-N Ĕgrileri } & $\mathbf{N}<\mathbf{1 0}^{\mathbf{6}}$ & & $\mathbf{N}>\mathbf{1 0}^{\mathbf{6}}$ & \\
\cline { 2 - 5 } & $\mathbf{l o g} \overline{\boldsymbol{K}}$ & $\mathbf{m}$ & $\mathbf{l o g} \overline{\boldsymbol{K}}$ & $\mathbf{m}$ \\
\hline Ortalama & 12.04 & 3 & 16.07 & 5 \\
Ortalama-StndrtSap & 11.81 & 3 & 15.84 & 5 \\
Ortalama-2*StndrtSap & 11.58 & 3 & 15.61 & 5 \\
Ortalama-3*StndrtSap & 11.35 & 3 & 15.37 & 5 \\
\hline
\end{tabular}

Tablo 10. 2TAK S-N eğrisi parametreleri

\begin{tabular}{lllll}
\hline \multirow{2}{*}{ S-N Ĕgrileri } & $\mathbf{N}<\mathbf{1 0}^{\mathbf{6}}$ & & $\mathbf{N}>\mathbf{1 0}^{\mathbf{6}}$ & \\
\cline { 2 - 5 } & $\mathbf{l o g} \overline{\boldsymbol{K}}$ & $\mathbf{m}$ & $\mathbf{l o g} \overline{\boldsymbol{K}}$ & $\mathbf{~ m}$ \\
\hline Ortalama & 11.01 & 3 & 14.35 & 5 \\
Ortalama-StndrtSap & 10.82 & 3 & 14.16 & 5 \\
Ortalama-2*StndrtSap & 10.63 & 3 & 13.97 & 5 \\
Ortalama-3*StndrtSap & 10.44 & 3 & 13.78 & 5 \\
\hline
\end{tabular}

Tablo 11. 3TKK S-N eğrisi parametreleri

\begin{tabular}{lllll}
\hline \multirow{2}{*}{ S-N Eğrileri } & $\mathbf{N}<\mathbf{1 0}^{\mathbf{6}}$ & \multicolumn{3}{c}{$\mathbf{N}>\mathbf{1 0}^{\mathbf{6}}$} \\
\cline { 2 - 5 } & $\mathbf{l o g} \overline{\boldsymbol{K}}$ & $\mathbf{m}$ & $\mathbf{l o g} \overline{\boldsymbol{K}}$ & $\mathbf{m}$ \\
\hline Ortalama & 12.18 & 3 & 15.64 & 5 \\
Ortalama-StndrtSap & 11.99 & 3 & 15.45 & 5 \\
Ortalama-2*StndrtSap & 11.80 & 3 & 15.26 & 5 \\
Ortalama-3*StndrtSap & 11.61 & 3 & 15.07 & 5 \\
\hline
\end{tabular}

Tablo 12. 3TAK S-N eğrisi parametreleri

\begin{tabular}{lllll}
\hline \multirow{2}{*}{ S-N Eğrileri } & $\mathbf{N}<\mathbf{1 0}^{\mathbf{6}}$ & \multicolumn{3}{c}{$\mathbf{N}>\mathbf{1 0}^{\mathbf{6}}$} \\
\cline { 2 - 5 } & $\mathbf{l o g} \overline{\boldsymbol{K}}$ & $\mathbf{m}$ & $\mathbf{l o g} \overline{\boldsymbol{K}}$ & $\mathbf{m}$ \\
\hline Ortalama & 11.30 & 3 & 14.83 & 5 \\
Ortalama-StndrtSap & 11.10 & 3 & 14.63 & 5 \\
Ortalama-2*StndrtSap & 10.90 & 3 & 14.43 & 5 \\
Ortalama-3*StndrtSap & 10.70 & 3 & 14.23 & 5 \\
\hline
\end{tabular}


Tablo 13. 15TAK S-N eğrisi parametreleri

\begin{tabular}{lllll}
\hline \multirow{2}{*}{ S-N Ĕgrileri } & $\mathbf{N}<\mathbf{1 0}^{\mathbf{6}}$ & & $\mathbf{N}>\mathbf{1 0}^{\mathbf{6}}$ & \\
\cline { 2 - 5 } & $\mathbf{l o g} \overline{\boldsymbol{K}}$ & $\mathbf{m}$ & $\mathbf{l o g} \overline{\boldsymbol{K}}$ & $\mathbf{m}$ \\
\hline Ortalama & 11.35 & 3 & 14.92 & 5 \\
Ortalama-StndrtSap & 10.77 & 3 & 14.77 & 5 \\
Ortalama-2*StndrtSap & 10.19 & 3 & 14.61 & 5 \\
Ortalama-3*StndrtSap & 9.61 & 3 & 14.46 & 5 \\
\hline
\end{tabular}

Genel olarak 2 ve 3 tonluk kancaların verileri karşılaştırıldığ zaman, 2 tonluk karbon kancaların belirli bir yük için 2 tonluk alaşım kancadan daha fazla döngüye dayanabildiğini ve 3 tonluk karbon kancaların belirli bir yük için 3 tonluk alaşım kancalardan daha fazla döngüye dayanabildiğini göstermektedir. Aşağıdaki eğrilerde verilen verilerle karşılaştırmalar yapılmıştır. Şekil 17 ve Şekil 18, sırasıyla tüm karbon ve alaşım kancaları için verileri derlemektedir. Şekil 17, test edilen 2 ton, 3 ton ve 25 ton karbon şaft kancaları için birleştirilmiş test sonuçları verileri kullanılarak üretilen S-N eğrilerini göstermektedir. Veri noktaları temsil amacıyla ayrı ayrı çizilmiştir. Şekil 18, 2 ton alaşım, 3 ton alaşım ve 15 ton alaşım kanca içeren test edilen tüm alaşım şaft kancaları için birleştirilmiş test sonuçları verileri kullanılarak oluşturulan S-N eğrilerini göstermektedir. Veri noktaları temsil amacıyla ayrı ayrı çizilmiştir. Tüm karbon kancalar için derlenmiş eğrinin ve 3 ton karbon kanca için S-N Eğrisinin hemen hemen aynı olduğu görülmektedir. Daha büyük kancaların daha az yorulma ömrüne sahip olması beklenilse de, yukarıdaki rakamlar bu eğilimi göstermemektedir. Herhangi bir boyuttaki kanca için S-N eğrilerinin benzer olduğu görülmüştür. Alaşım kancaları için derlenmiş S$\mathrm{N}$ eğrileri, herhangi bir alaşım kancası boyutu için kullanılabileceği ve yorulma tasarımı S-N eğrileri için; ortalamanın standart sapmasının iki veya üç kat daha negatif olması önerilmektedir. Aşağıda verilen tablolar yapılan analizlerden elde edilen test verileri ve yapılan analizlerde 25 tonluk karbon kanca hariç bütün kanca tipleri için elde edilen S-N eğrileri Şekil 12'den Şekil 18 'e kadar verilmiştir.

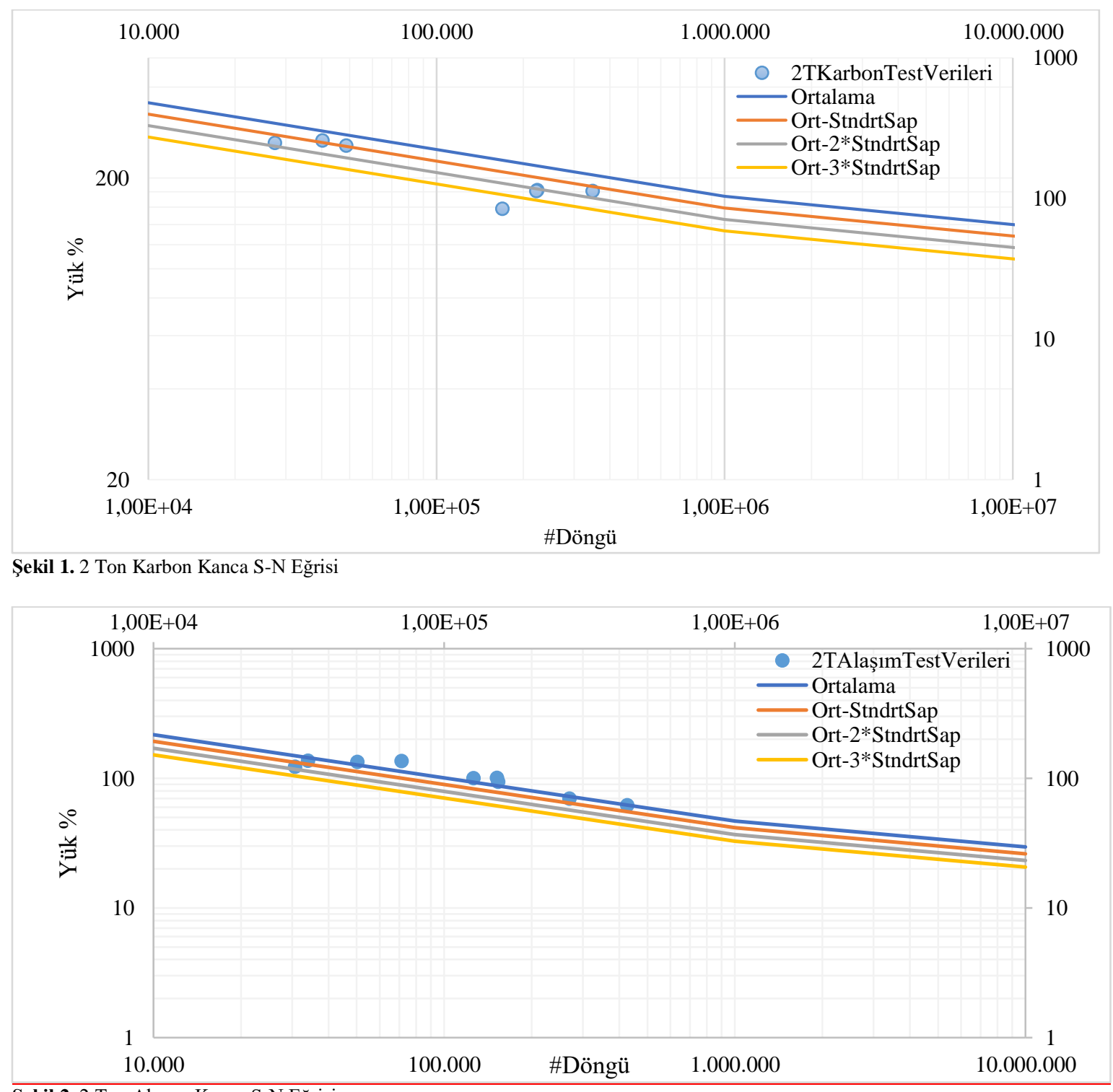

Şekil 2. 2 Ton Alaşım Kanca S-N Eğrisi 


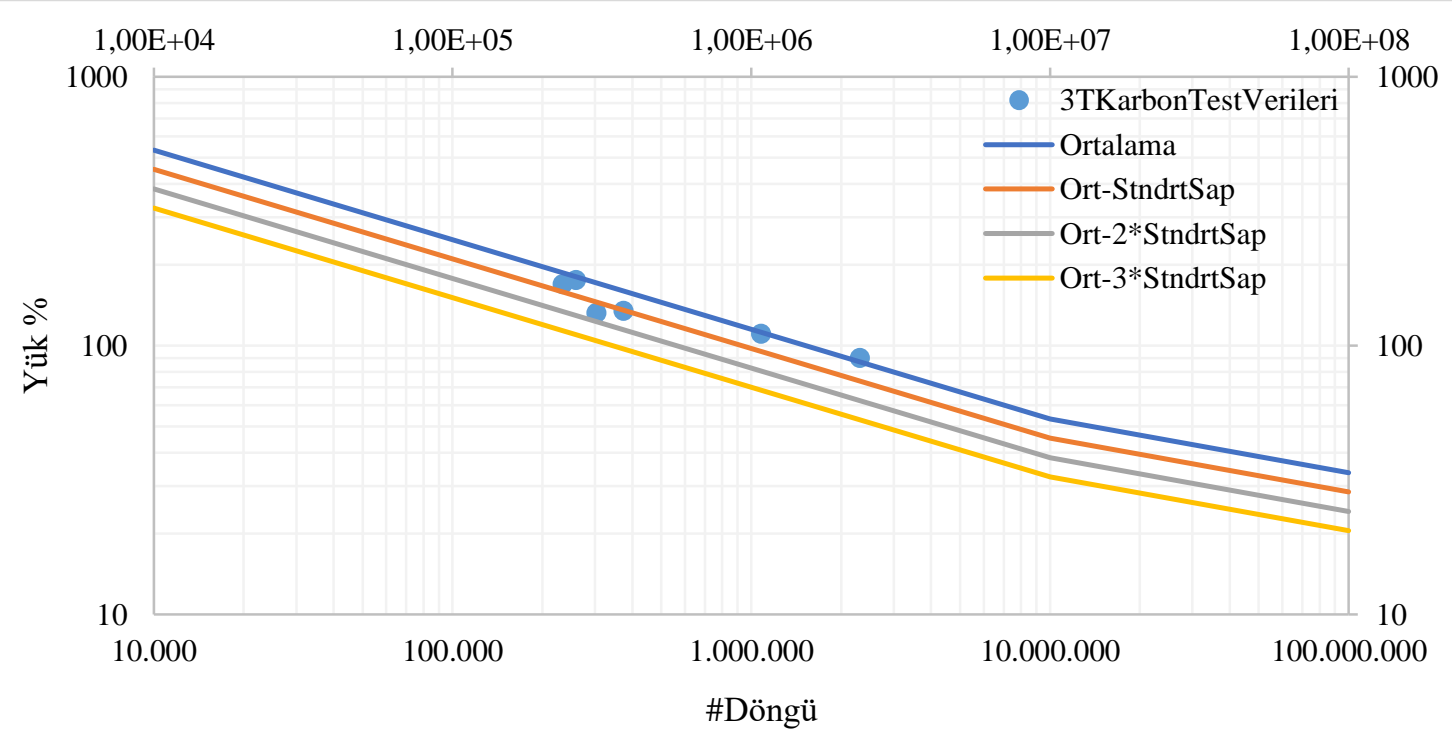

Şekil 3. 3 Ton Karbon Kanca S-N Eğrisi

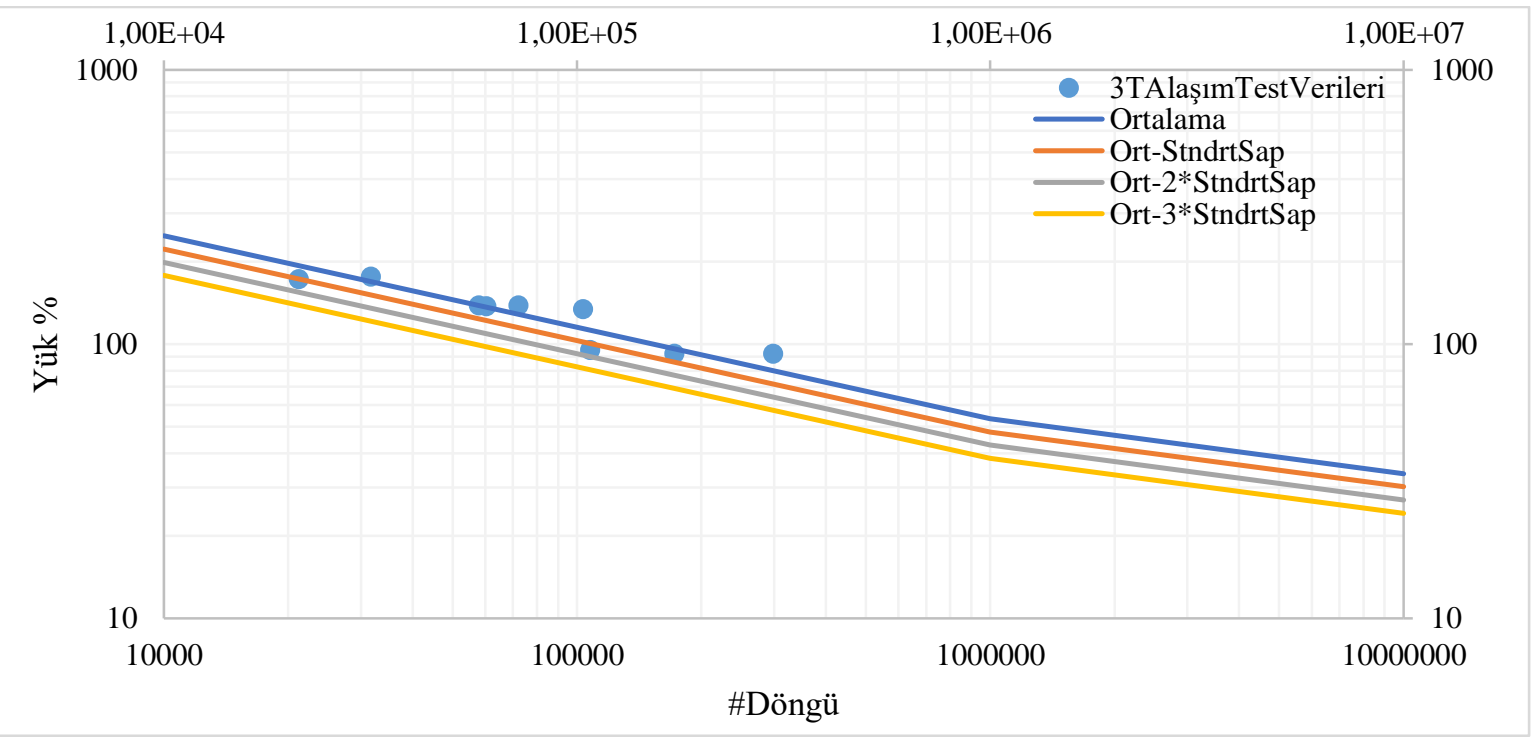

Şekil 4. 3 Ton Alaşım Kanca S-N Eğrisi

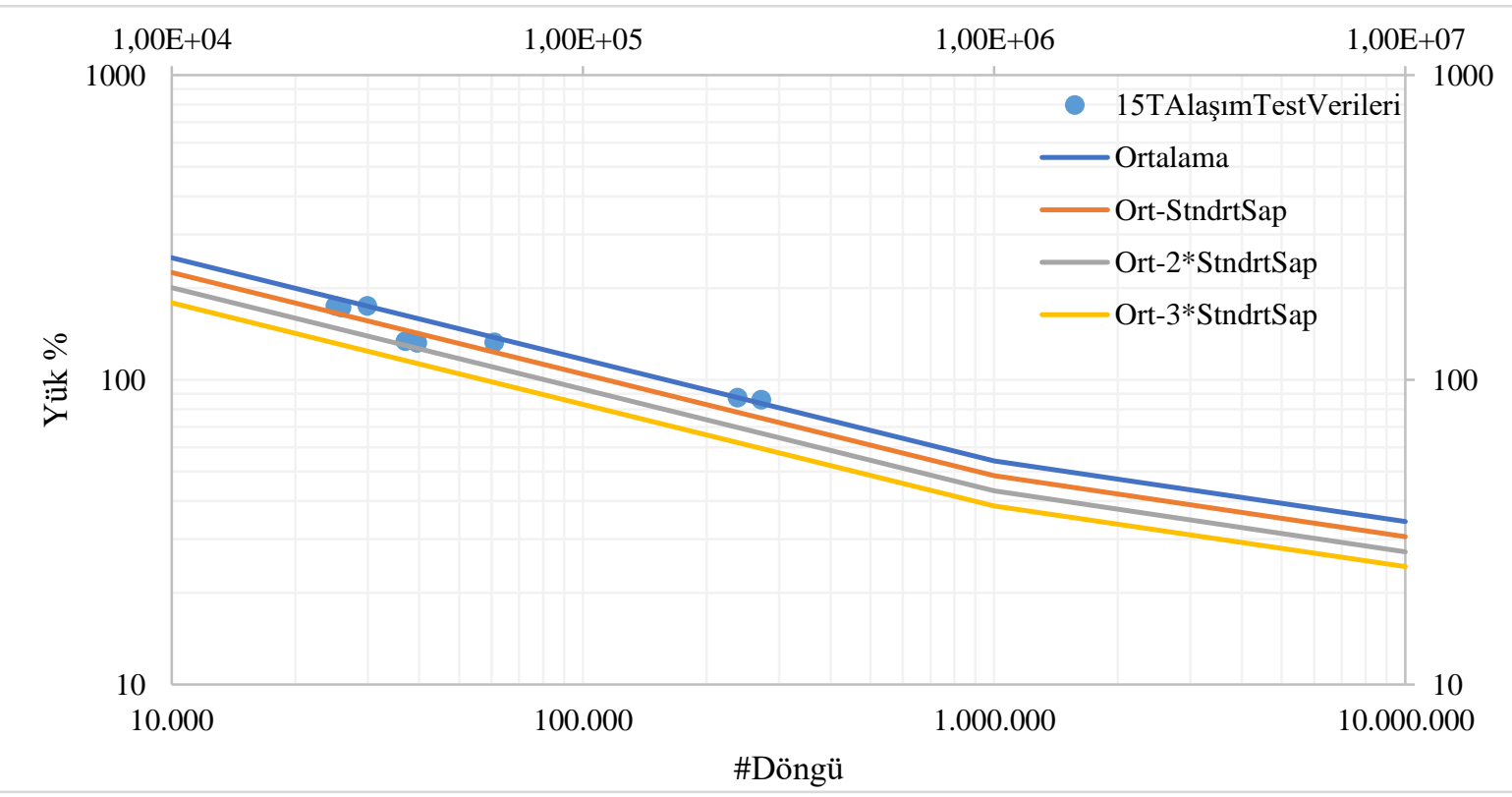

Şekil 5. 15 Ton Alaşım Kanca S-N Eğrisi 


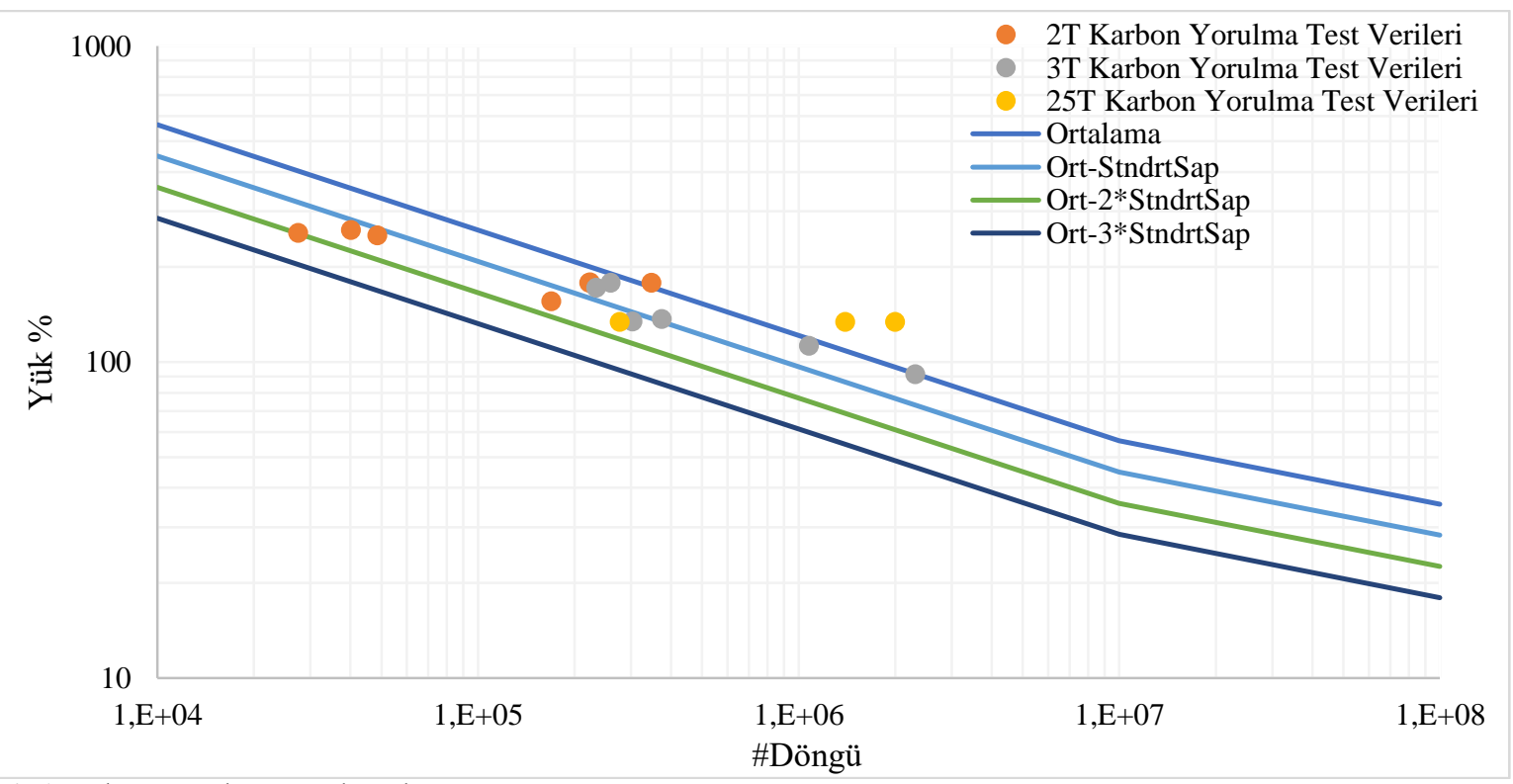

Şekil 6. Karbon Kancaların Karşılaştırılması

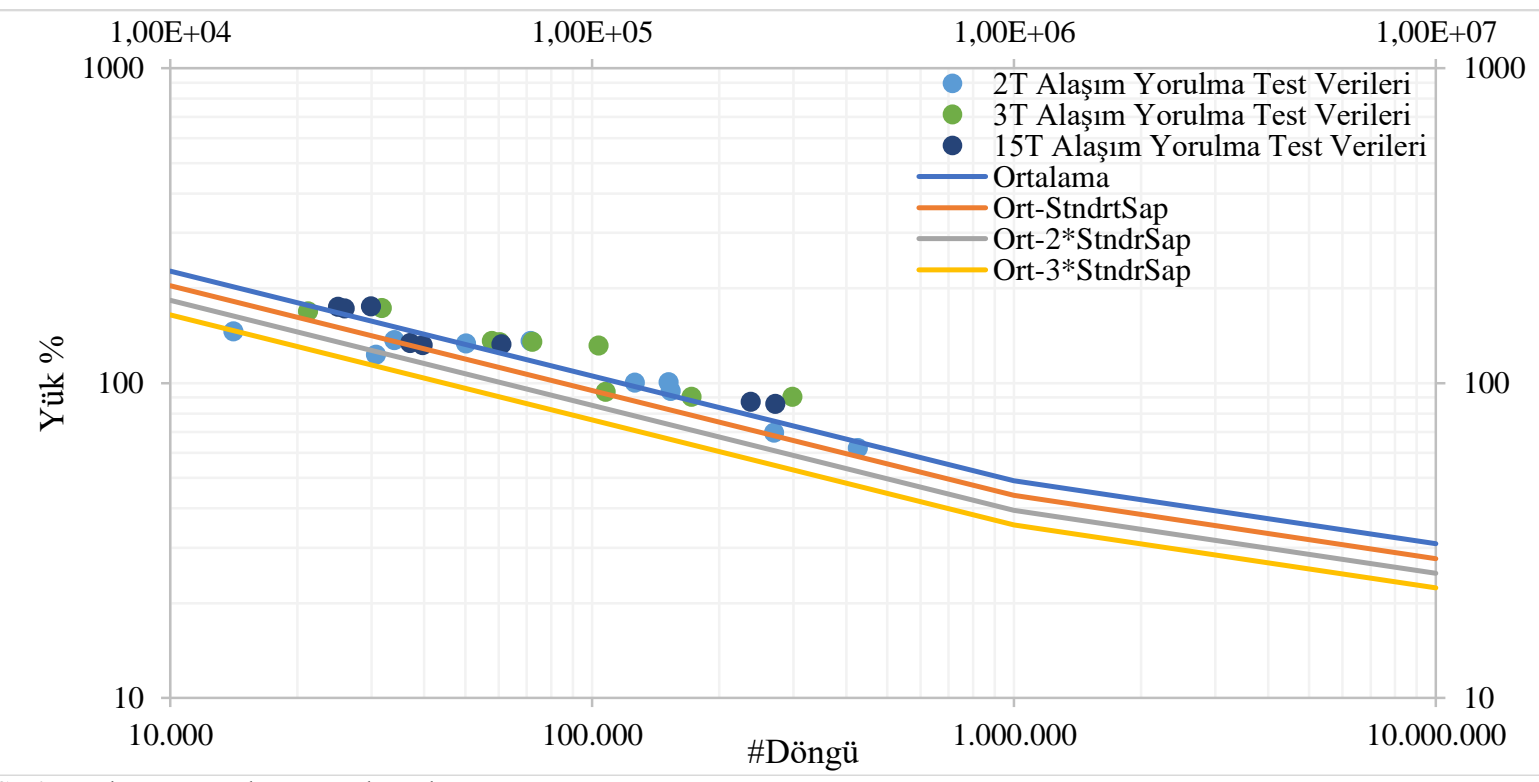

Şekil 7. Alaşım Kancaların Karşılaştırılması

\section{SONUÇ}

$\mathrm{Bu}$ çalışmada seçilen kanca tipleri olan 2 ton karbon, 2 ton alaşım, 3 ton karbon, 3 ton alaşım, 15 ton alaşım ve 25 ton karbon kancalar için 6 adet statik ve 47 adet yorulma testleri yapılmıştır. Statik testler ve yorulma testlerinde alaşım ve karbon malzemeden imal edilmiş kanca tipleri karşılaştırılmıştır. Yorulma testlerindeki veriler kullanılarak elde edilmiş S-N eğrileri ile kanca tiplerine göre yorulma ömürleri irdelenmiştir. Çalışma kapsamında elde edilen önemli sonuçlar aşağıda verildiği gibidir:

-Statik test sonuçlarında elde edilen en büyük çekme yükü değerleri göz önüne alındığından karbon kancaların alaşım kancalara göre daha yüksek çekme kapasitelerine sahip olduğu görülmüştür.

-Yorulma testine tabii tutulmuş ve tutulmadan statik testleri yapılan kancalar incelendiğinde; bir kanca yük kapasitesinin, düşük çalışma yükü koşullarında yorulma testine tabi tutulduktan sonra önemli ölçüde değişmediği görülmüştür.

- Çalışmada meydana gelen göçmelerin genel olarak 2 farklı bölgede meydana geldiği görülmektedir. Ana göçme tipi olarak kanca gövdesinde meydana gelen göçmeler kabul edilebilir. Diğer göçme tipi ise alaşım kancalarda daha fazla gözlemlenen şaft birleşiminde meydana gelen göçmelerdir.

-Çalışmada elde edilen S-N eğrilerine bakıldığı zaman kanca kapasitesine yani kancanın boyutuna göre yorulma eğrilerinde bir değişiklik gözlemlenmemiştir. $\mathrm{Bu}$, yorulma ömrü göz önüne alındığında kanca boyutunun küçük bir etkiye sahip olduğunu göstermektedir.

-S-N eğrileri incelendiğinde karbon malzemeden imal edilmiş kancaların alaşım malzemeden imal edilmiş kancalara göre daha uzun yorulma ömrüne sahip olduğu görülmektedir.

-S-N eğrileri hem ortalama hem de ortalama-1, -2, -3 standart sapma eğrilerini de içermektedir. Yorulma durumu dikkate alınarak yapılan tasarımlar için ortalama-2 veya ortalama-3 standart sapma durumlarının 
dikkate alınması test numuneleri ile arasında olan uyum nedeniyle bu çalışmada önerilmektedir.

\section{KAYNAKLAR}

[1] Sundriyal R. Stress Analysis of Crane Hook with Different Cross Sections Using ANSYS, Int. J. Sci. Res.2017; vol. 6, no. 8, pp. 1363-1368.

[2] Kökçü İ. Kule Vinci Tasarımı ve Analizi, Balıkesir Üniversitesi Fen Bilimleri Enstitüsü.2015.

[3] Çoktu AK, Ceylan S. Kaldirma araçlarinda iş sağliği ve güvenliği.2012.

[4] Nazlioğlu A. İnşaat sektöründe kullanilan kule vinçler ile yapilan çalişmalarda karşilaşilan risklerin tespiti ve korunma yollari, Çalışma ve Sosyal Güvenlik Bakanlığı.2014.

[5] Urul H. Yapı İşyerlerinde Kullanılan Vinçlerle Yapılan Çalışmalarda Alınması Gereken İş Sağlığı ve Güvenliği Önlemleri.2013.

[6] Nazlioğlu A, Karakavak A, Aydos MR, Taş N. Kule vinçlerin güvenli kullanimina ilişkin uygulama rehberi.2018.

[7] Gerdemeli İ. Yük Tutma Elemanları, in Transport Tekniğinde İleri Konular,2019; pp. 1-25.

[8] Anonim. DIN-15400 Lifting hooks; materials, mechanical properties, lifting capacity and stresses. Germany.1990.

[9] Anonim. Din-17102 Weldable Normalızed Fine Grain Structural Steels - Technical Delivery Conditions For Plate, Strip, Wide Flats, Sections And Bars. Germany. 1983.

[10] Anonim. Din-17103 Weldable Fine Grain Structural Steel Forgings - Technical Delivery Conditions. Germany. 1989.

[11] Sonsino CM. Course of SN-curves especially in the high-cycle fatigue regime with regard to component design and safety, Int. J. Fatigue,2007; vol. 29, pp. 2246-2258.

[12] Qin YX, Xie WT, Ren HP, Li X. Crane hook stress analysis upon boundary interpolated reproducing kernel particle method, Eng. Anal. Bound. Elem.,2016; vol. 63, pp. 74-81.

[13] Torres Y, Gallardo JM, Domínguez J, Jiménez FJE. Brittle fracture of a crane hook, Eng. Fail. Anal., 2010; vol. 17, no. 1, pp. 38-47.

[14] Vinodh S, Ravikumar R. Application of probabilistic finite element analysis for crane hook design, J. Eng. Des. Technol., 2012; vol. 10, no. 2, pp. 255-275.

[15] Bergaley A, Purohit A. Structural Analysis of Crane Hook Using Finite Element Method, Int. J. Sci. Mod. Eng., 2013; vol. 1, no. 10, pp. 3-7.

[16] Desai N, Zeytinoglu N. Design and Optimization of the Geometric Properties of a Crane Hook, World J. Eng. Technol., 2016; vol. 4, no. August, pp. 391397.

[17] Sahu S, Dewangan R, Patnaik M, Yadav N. Study of Crane Hook Having Trapezoidal Section by Finite Element Method \& Design of Experiments, Int. J. Mod. Eng. Res., 2012; vol. 2, no. 4, pp. 2779-2781.

[18] Liu YB. Prediction of the S-N curves of highstrength steels in the very high cycle fatigue regime, Int. J. Fatigue, 2010; vol. 32, no. 8, pp. 1351-1357.

[19] Richard HA, Sander M. Fundamentals of fracture mechanics, in Solid Mechanics and its Applications. 2016.

[20] Paris WAP, Gomez M, Paris PC, Gomez MP, Anderson WEP. A Rational Analytic Theory of Fatigue, Trend Eng. 1961.

[21] Korkut S. What is a SN-Curve?, Siemens Digital Industries Software, . https :// community. sw.siemens.com/s/article/what-is-a-sn-curve (accessed Apr. 30, 2020).2019. 